\title{
ANALISIS KESESUIAN STRATEGI PEMASARAN TERHADAP MAQASHID SYARIAH (STUDI KASUS DI BMT BINA INSAN SEJAHTERA MANDIRI)
}

\author{
Zainal Arif, Farhatun Dina Nisah, \\ Dhany Hermawan, Muh Turizal Husein \\ zarifpambon@gmail.com, farhatundina@gmail.com, abiturizal68@ gmail.com
} (Fakultas Agama Islam, Universitas Muhammadiyah Tangerang)

\begin{abstract}
Abstrak:
Mempertahankan kelangsungan dan berkembangnya perusahaan membutuhkan strategi pemasaran yang baik dan professional. Tujuan dari ketentuan syariah yaitu terwujudnya keberkahan dan kasih sayang bagi semesta alam. Praktek dari kerahmatan syariah adalah apabila maqashid syariah telah dijalankan yang meliputi perlindungan terhadap agama (hifzh din), perlindungan terhadap akal (hifzh aql), perlindungan terhadap harta benda (hifzh maal), perlindungan terhadap jiwa (hifzh nafs), dan perlindungan terhadap keturunan atau kehormatan (hifzh nasl). Berdasarkan hasil penelitian ini, dapat disimpulkan bahwa kesesuaian strategi pemasaran terhadap maqashid syariah yang dilakukan di Koperasi Syariah BMT BISMA sesuai dengan maqashid syariah dan sudah dapat dirasakan masyarakat secara langsung, namun pihak internal BMT BISMA perlu untuk meningkatkan pengetahuan ilmu ekonomi Islam, salah satunya dengan mengadakan kajian ilmu ekonomi Islam yang belum diketahui agar dapat menjadi pegangan dalam memberikan edukasi dan mensosialisasikan ekonomi Islam kepada masyarakat mengingat maqashid syariah merupakan kunci dari kemaslahatan umat.
\end{abstract}

\section{Kata Kunci: Strategi Pemasaran, dan Maqashid Syariah}

\section{A. Latar Belakang Masalah}

Pentingnya peranan strategi pemasaran dalam suatu perusahaan. Di dalam perusahaan harus melihat situasi dan kondisi pasar serta menilai kedudukan atau posisi perusahaan dipasar. ${ }^{1}$ Setiap perusahaan dalam memasarkan produk yang dihasilkannya menjalankan strategi pemasaran, sehingga dapat mencapai sasaran yang diharapkannya. Strategi pemasaran dapat dinyatakan sebagai dasar tindakan yang mengarahkan kegiatan atau usaha pemasaran dan suatu perusahaan, dalam kondisi persaingan dan lingkungan yang selalu berubah, agar dapat mencapai tujuan yang diharapkan. Jadi dalam

\footnotetext{
${ }^{1}$ Sofjan Assauri, Manajemen Pemasaran, (Jakarta: Rajawali Pers, 2011), h. 167.
}

menetapkan strategi pemasaran yang akan dijalankan, perusahaan harus lebih dahulu melihat situasi dan kondisi pasar serta menilai posisinya di pasar. ${ }^{2}$

Tujuan pemasaran di dalam Islam bukan semata-mata meraih keuntungan, melainkan mendapatkan keridhaan dari Allah SWT. Syariat Islam turut menetapkan cara dan kaidah tersendiri untuk membelanjakan harta seperti zakat pada harta-harta tertentu, sedekah, dan pemberian hadiah dalam keadaan tertentu. Sistem muammalah Islam dengan keimanan yang jelas, akan mengawal aktivitas pemasaran yang selaras dengan kelangsungan hidup manusia yang bermartabat, berakhlak dan beradab.

${ }^{2}$ Ibid., h. 170 . 
Segala bentuk pemasaran yang bertentangan dengan maqashid syariah tidak akan diterima dan akan menimbulkan masalah dikemudian hari. ${ }^{3}$ Dalam setiap aspek dan kegiatan usaha haruslah mengimplementasikan akhlakul karimah agar dapat menuju kesejahteraan manusia dan kehidupan yang lebih baik. Sebagaimana tujuan dari ketentuan syariah yaitu terwujudnya keberkahan dan kasih sayang bagi semesta alam (rahmatan lil alamin). Praktek dari kerahmatan syariah adalah apabila maqashid syariah telah dijalankan yang meliputi perlindungan terhadap agama (hifzh din), perlindungan terhadap akal (hifzh aql), perlindungan terhadap harta benda (hifzh maal), perlindungan terhadap jiwa (hifzh nafs), dan perlindungan terhadap keturunan atau kehormatan (hifzh nasl). Agar penggunaan maqashid syariah sangat diperlukan pada setiap perbankan syariah. Semua perkembangan yang terjadi dapat disimpulkan bermuara pada suatu prinsip yang sangat fundamental, yaitu bahwa manusia tidak mungkin perlakukan sesuai dengan produksi lainnya, melainkan harus diperlakukan sesuai dengan harkat dan martabatnya. ${ }^{4}$

Adapun kesesuaian strategi pemasaran terhadap maqashid syariah diantaranya mencakup; Asas suka sama suka, Asas keadilan, Asas saling menguntungkan, dan Asas tolongmenolong. Disamping itu diperlukannya mekanisme dan SOP (Standar Operasional Prosedur) yang sesuai dengan ketentuan yang berlaku. Saat ini tidak hanya lembaga keuangan syariah berskala besar yang mampu berkembang seperti bank syariah. Namun, lembaga keuangan syariah berskala kecil pun mulai menunjukan perkembangan seperti halnya Koperasi

\footnotetext{
${ }^{3}$ Veithzal Rivai Zainal, Islamic Marketing Management, (Jakarta: PT. Bumi Aksara, 2017).

${ }^{4}$ Sondang P. Siagan, Manajemen Sumber Daya Manusia (Jakarta: Bumi Aksara, 2008)
}

Syariah Baitul Maal wat Tamwil (BMT). Baitul Maal wat Tamwil (BMT) merupakan lembaga keuangan mikro pendukung kegiatan ekonomi masyarakat bawah dan kecil yang dijalankan berdasarkan syariat Islam. ${ }^{5}$ Undangundang Republik Indonesia No. 25 Tahun 1992 tentang perkoperasian yakni, koperasi adalah Badan Usaha yang beranggotakan orang-seorang atau Badan hukum koperasi dengan melandaskan kegiatannya berdasarkan prinsip koperasi sekaligus sebagai gerakan ekonomi rakyat yang berdasar atas asas kekeluargaan. ${ }^{6}$ Salah satu BMT yang sedang tumbuh dan berkembang adalah BMT BISMA (Bina Insan Sejahtera Mandiri). BMT BISMA merupakan salah satu badan usaha yang bergerak di bidang penyediaan jasa simpanan dan pembiayaan bagi masyarakat, yang terletak di Jalan Layar 1 No. 37 Kelapa Dua Tangerang Banten. BMT BISMA berdiri dengan gagasan fleksibel dalam menjangkau kalangan masyarakat bawah, yaitu mengembangkan usaha-usaha produktif dan investasi dalam meningkatkan kegiatan ekonomi pengusaha kecil bawah yang berdasarkan pada prinsip syariah dan sesuai dengan maqashid syariah. Selain itu, BMT BISMA sebagai lembaga keuangan yang menghimpun dana dan menyalurkannya kembali pada masyarakat harus mampu menjalankan peran manajemen dengan baik, karena baik buruknya manajemen yang dijalankan oleh suatu BMT akan berpengaruh pada nasabah/anggota terhadap BMT tersebut. Adapun skripsi ini bertujuan karena adanya keingitahuan dari peneliti sejauh mana tentang efektifitas kesesuaian strategi pemasaran dengan

\footnotetext{
${ }^{5}$ Muhamad Ridwan, Sistem dan Prosedur Pendirian BMT (Baitul Maal Wat Tanwil), (Yogyakarta: Citra Media, 2006).

${ }^{6}$ Abdullah Fathoni, Manajemen Risiko Kontemporer Bank. Koperasi dan BMT (Jakarta: Yayasan Pendidikan Nur Azza Lestari, 2015
} 
kondisi perekonomian saat ini dengan kaitan kesyariahannya sebagai sebuah Koperasi Syariah BMT BISMA.

Maka berdasarkan uraian diatas, penulis bermaksud untuk mengetahui lebih lanjut lagi untuk membahas mengenai "Analisis Kesesuaian Strategi Pemasaran Terhadap Maqashid Syariah (Studi Kasus Di BMT BISMA)". Berdasarkan latar belakang masalah diatas, maka peneliti merumuskan permasalahan penelitian sebagai berikut:

1. Bagaimana strategi pemasaran yang dilakukan oleh BMT BISMA?

2. Bagaimana kesesuaian strategi pemasaran terhadap maqashid syariah di BMT BISMA?

Penelitian ini diharapkan dapat memberikan sumbangan pemikiran dalam kesesuaian strategi pemasaran terhadap pencapaian Maqashid Syariah di Koperasi Syariah Baitul Maal wa Tamwil (BMT) Bina Insan Sejahtera Mandiri.

\section{B. Landasan Teori}

1. Strategi Pemasaran

a. Pengertian Strategi

Kata "Strategi" berasal dari bahasa Yunani, yaitu "Strategos" yang berarti "generalship" atau sesuatu yang dikerjakan oleh para jenderal perang dalam membuat rencana untuk memenangkan perang. Secara umum strategi didefinisikan sebagai cara mencapai tujuan. Strategi merupakan rencana jangka panjang untuk mencapai tujuan. Menurut Michel Porter dalam artikelnya yang berjudul Competitive Strategy dalam Harvad Business Review menyatakan bahwa strategi adalah sekumpulan tindakan atau aktivitas yang berbeda untuk mengantarkan nilai. Menurut Thompson dan Strikcland menegaskan strategi terdiri atas aktivitasaktivitas yang penuh daya saing serta pendekatan-pendekatan bisnis untuk mencapai kinerja yang memuaskan (sesuai target). ${ }^{7}$

Menurut Markides ia mengajukan rumusan bahwa strategi merupakan pengambilan keputusan menyangkut tiga parameter utama: (1) siapa yang menjadi target pelanggan dan siapa yang tidak akan ditarget (dimensi Who); (2) produk dan jasa apa yang bakal ditawarkan kepada para pelanggan sasaran dan produk/jasa apa yang tidak akan ditawarkan (dimensi What); dan (3) aktivitas apa yang akan dan tidak akan dilakukan dalam rangka mewujudkan itu semua (dimensi How). Markides menekankan pentingnya pilihan strategi menyangkut apa yang bakal menjadi fokus organisasi dan apa yang tidak akan dilakukan organisasi.

Adapun Oliver mengklasifikasikan evolusi pemikiran strategi dalam empat metafora. Pertama, strategi sebagai (war) atau olahraga (sport), yang fokus utamanya adalah memenangkan perang dengan cara mengalahkan atau mengeliminasi para pesaing. Kedua, strategi sebagai mesin (machine), yang menekankan proses mekanistik dalam perencanaan sistematis. Ketiga, strategi sebagai jejaring (network), dengan penekanan pada proses perencanaan global, organisasi berbasis informasi, dan pengakuan atas peran sumber daya manusia sebagai sumber daya kunci. Keempat, strategi sebagai biologi yang berfokus pada peran penting pelanggan dan relasinya dengan ekologi perusahaan. Pelanggan berpartisipasi dalam formulasi strategi dan mempengaruhi kelangsungan hidup perusahaan sebagaimana organisme hidup berinteraksi dengan lingkungannya. Oliver meyakini bahwa metafora strategi sebagai biologi merupakan perspektif yang dominan saat ini. ${ }^{8}$

\footnotetext{
${ }^{7}$ Rachmat, Manajemen Strategik, (Bandung: CV Pustaka Setia, 2014), h. 2.

${ }^{8}$ Fandy Tjiptono, Strategi Pemasaran, (Yogyakarta: Penerbit Andi, 2015), h. 4-5
} 


\section{b. Pengertian Pemasaran}

Pemasaran berkembang dari yang semula hanya bagian dari ekonomika menjadi sebuah disiplin ilmu tersendiri. Kata marketing masuk dalam kosa kata bahasa inggris pertama kali pada tahun 1561. Perkembangan pesat langsung pasca revolusi industri di abad 18. Bahkan sebagian pasar menyebutkan bahwa cikal bakal pemikiran pemasaran modern dapat ditelusuri pada karya klasik Adam Smith di tahun 1776 yang berjudul 'An Inquiry into the Nature and Causes of the Wealth of Natios. Dalam bukunya tersebut, Adam Smith menekankan pentingnya memperhatikan kepentingan pelanggan. ${ }^{9}$ emasaran berhubungan dan berkaitan erat dengan suatu proses mengidentifikasi dan memenuhi kebutuhan manusia dan masyarakat. Pembuatan suatu produk haruslah berdasarkan apa yang menjadi kebutuhan dan keinginan dari konsumen, sehingga produk yang dibuat benar-benar yang menjadi kebutuhan konsumen. Asosiasi pemasaran Amerika mendefinsikan pemasaran, yaitu pemasaran adalah suatu fungsi organisasi dan seperangkat proses untuk menciptakan, mengkomunikasikan, dan menyerahkan nilai kepada pelanggan dengan cara yang menguntungkan organisasi dan pemilik saham. American Marketing Association (AMA) menawarkan definisi formal pemasaran adalah suatu fungsi organisasi dan serangkaian proses untuk menciptakan, mengkomunikasikan, dan memberikan nilai kepada pelanggan dan untuk mengelola hubungan pelanggan dengan cara yang menguntungkan organisasi dan pemangku kepentingannya. ${ }^{10}$ Peter Drucker, ahli teori manajemen terkemuka, menjelaskan pemasaran sebagai berikut: Selalu ada kebutuhan akan penjualan.

\footnotetext{
${ }^{9}$ Tjiptono, Strategi Pemasaran, h. 1.

${ }^{10}$ Philip Kotler, Manajemen Pemasaran, (Jakarta: Salemba Empat, 1999), h. 5
}

Namun tujuan dari pemasaran adalah membuat penjualan berlimpah. Tujuan pemasaran adalah mengetahui dan memahami pelanggan dengan baik sehingga produk atau jasa bisa sesuai dengan kebutuhannya menghasilkan seorang pelanggan yang siap untuk membeli. Dengan demikian yang dibutuhkan hanyalah memastikan produk dan jasa tersedia. ${ }^{11}$

Kotler dan AB Susanto memberikan definisi pemasaran adalah suatu proses sosial dan manajerial dimana individu dan kelompok mendapatkan kebutuhan dan keinginan mereka dengan menciptakan, menawarkan, dan bertukar sesuatu yang bernilai satu sama lain. Sehinggga secara umum pemasaran dapat diartikan sebagai suatu proses sosial yang merancang dan menawarkan sesuatu yang menjadi kebutuhan dan keinginan dari masyarakat atau konsumen dalam rangka memberikan kepuasan yang optimal kepada masyarakat atau konsumen.

Landasan Al Qur'an surat An-Nisa (4): 29:

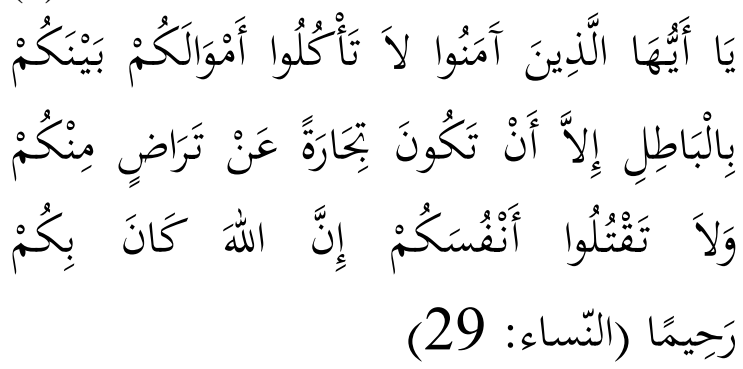

Wahai orang-orang yang beriman, janganlah kalian memakan harta-harta kalian di antara kalian dengan cara yang batil, kecuali dengan perdagangan yang kalian saling ridha. Dan janganlah kalian membunuh diri-diri kalian, sesungguhnya Allah itu Maha Kasih Sayang kepada kalian. (QS. An-Nisa: 29)

\footnotetext{
${ }^{11}$ Ibid., h. 5-6.

${ }^{12}$ M. Nur Rianto, Dasar-Dasar Pemasaran
} Bank Syariah, (Bandung: CV Alfabeta, 2012), h. 6. 


\section{c. Pengertian Strategi Pemasaran}

Menurut Chandra, strategi pemasaran merupakan rencana yang menjabarkan ekspektasi perusahaan akan dampak dari berbagai aktivitas atau program pemasaran terhadap permintaan produk atau lini produknya di pasar sasaran tertentu. Program pemasaran meliputi tindakantindakan pemasaran yang dapat mempengaruhi permintaan terhadap produk, diantaranya dalam hal mengubah harga, memodifikasi kampanye iklan, merancang promosi khusus, menentukan pilihan saluran distribusi, dan sebagainya. Salah satu definisi yang baik dan singkat dari pemasaran itu sendiri adalah memenuhi kebutuhan dengan cara yang menguntungkan.

Strategi pemasaran pada dasarnya adalah rencana yang meyeluruh, terpadu dan menyatu di bidang pemasaran, yang memberikan panduan tentang kegiatan yang akan dijalankan untuk dapat tercapainya tujuan pemasaran suatu peruasahaan. Dengan kata lain, strategi pemasaran adalah serangkaian tujuan dan sasaran, kebijakan dan aturan yang memberi arah kepada usaha-usaha pemasaran perusahaan dari waktu ke waktu, pada masing-masing tingkatan dan acuan serta alokasinya, terutama sebagai tanggapan perusahan dalam menghadapi lingkungan melalui analisis kesempatan dan ancaman yang dihadapi perusahaan dari lingkungannya. Disamping itu strategi pemasaran yang telah ditetapkan dan dijalankan, harus dinilai kembali, apakah masih sesuai dengan keadaan/kondisi pada saat ini. Penilaian atau evaluasi ini menggunakan analisis keunggulan, kelemahan, kesempatan, dan ancaman.

Faktor lingkungan yang dianalisis dalam penyusutan strategi pemasaran adalah keadaan pasar atau persaingan, perkembangan teknologi, keadaan ekonomi, peraturan dan kebijakan pemerintah, keadaan sosial budaya, dan keadaan politik. Masing-masing faktor ini dapat menimbulkan adanya kesempatan atau ancaman/hambatan bagi pemasaran produk suatu perusahaan. Faktor internal perusahaan yang dianalisis dalam penyusunan strategi pemasaran adalah faktor yang terkait dengan pelaksanaan fungsi perusahaan, yang meliputi keuangan/pembelanjaan, pemasaran, produksi serta organisasi dan sumber daya manusia. Masing-masing faktor internal yang terkait dengan fungsi perusahaan tersebut dapat merupakan hal yang menunjukkan adanya keunggualan atau kelemahan perusahaan. Adapun untuk menjalankan kegiatan pemasaran tersebut secara baik dan juga sesuai dengan sasaran yang diharapkan perusahaan. Khusus dalam bidang pemasaran, faktor-faktor lingkungan atau eksternal seperti telah diuraikan di atas, adalah faktor yang tidak dapat dikendalikan oleh pimpinan perusahaan. ${ }^{13}$

\section{Segmentasi Pasar}

Segmentasi pasar adalah proses pengelompokan kedalam kelompok pembeli yang potensial yang memiliki kebutuhan yang sama atau karakteristik yang disukai serta memperlihatkan hubungan pembelian yang sama. Dengan segmentasi pasar, perusahaan dapat lebih fokus mengalokasikan sumber daya, memberikan gambaran bagi perusahaan untuk menetapkan segmen yang potensial, dan dapat menetukan cara-cara promosi yang efektif. Dalam melakukan segmentasi pasar, terdapat beberapa cara. Segmentasi dapat dilakukan berdasarkan geografis, demografis, psikologis dan perilaku yang dapat digunkan secara tersendiri atau gabungan. Secara garis besarnya, dasar-dasar segmentasi pasar dijelaskan sebagai berikut:

a. Orang dengan keinginan: segmentasi dilakukan menurut dasar geografis dan demografis.

\footnotetext{
${ }^{13}$ Assauri, Manajemen Pemasaran, h. 5.
} 
b. Adanya uang untuk dibelanjakan: segmentasi dilakukan berdasarkan daya beli konsumen (distribusi pendapatan)

c. Kemauan untuk membelanjakan: segmentasi dilakukan dengan melihat perilaku beli konsumen. ${ }^{14}$

Tujuan dari segmentasi pasar adalah agar kegiatan organisasi pemasaran lebih terarah sehingga dapat menentukan segmen pasar mana yang akan lebih di utamakan, agar sumber daya yang ada dapat dimanfaatkan semaksimal mungkin dengan tingkat efesiensi yang tinggi, dan agar perusahaan dapat lebih berkompetitif.

\section{Target Pasar}

Perusahaan berusaha memilih pasar yang dapat memberikan peluang maksimum untuk mencapai tujuan. Perusahaan akan menikmati keuntungan apabila memperoleh posisi tertentu di pasar sasaran. Segmen pasar dianggap menarik apabila mempunayai sifat-sifat sebagai berikut:

1) Segemen pasar tersebut cukup besar

2) Segmen pasar tersebut mungkin kecil, tetapi sangat potensial untuk berkembang lebih lanjut karena tidak dikuasai oleh pesaing yang ada sekarang

3) Segmen pasar tersebut masih membutuhkan sesuatu yang dapat dilayani atau dipenuhi oleh perusahaan

4) Segmen pasar tersebut dapat dibedakan dari segmen-segmen lainnya. ${ }^{15}$

Untuk mencapai posisi yang kuat, perusahaan harus dapat memasuki segmen pasar yang diperkirakan akan menghasilkan tingkat laba yang besar. Pilihan strategi penentuan posisi di pasar sasaran sangat membantu pembuatan produk, calon pembeli yang akan dilayani, dan pesaing yang akan dihadapi oleh perusahaan.

\footnotetext{
${ }^{14}$ Kotler, Manajemen Pemasaran di Indonesia, h. 228.

${ }^{15}$ Kotler, Manajemen Pemasaran di Indonesia, h. 249.
}

\section{Positioning (Pemosisian)}

Setelah memutuskan segmen pasar mana yang akan dimasuki, perusahaan harus memutuskan positioning ini adalah untuk membedakan persepsi perusahaan berikut produk dan jasanya dari pesaing. Positioning dalam produk barang mengkomunikasikan atribut dari barang tersebut. Namun dalam produk jasa, atribut yang di komunikasikan seputar karakteristik jasa.

Langkah-langkah dalam positioning, menurut Kotler setidaknya ada tiga langkah dalam melakukan positioning, yakni:

a. Mengenali keunggulan-keunggulan yang mungkin dapat ditampilkan dalam hubungan pesaing

b. Memilih keunggulan-keunggulan yang paling kuat/menonjol

c. Menyampaikan keunggulan secara efektif kepada target pasar. ${ }^{16}$

\section{a. Strategi Pemasaran Secara Umum}

Semua pengelompokan konsumen yang telah dilakukan oleh para ahli pemasaran yang didasarkan pada berbagai kriteria, bertujuan untuk mengetahui sifatsifat perilaku konsumen dalam melakukan pembeliannya. Dalam hubungan strategi pemasaran secara umum ini, dapat dibedakan tiga jenis strategi pemasaran yang dapat ditempuh perusahaan, yaitu:

1) Strategi yang tidak membeda-bedakan pasar. Dengan strategi ini, perusahaan menganggap pasar sebagai suatu keseluruhan, sehingga perusahaan hanya memperhatikan kebutuhan konsumen secara umum. Oleh karena itu perusahaan hanya menghasilkan dan memasarkan satu macam produk saja dan berusaha menarik semua pembeli dan calon pembeli dengan suatu rencana pemasaran saja.

2) Strategi pemasaran yang membedabedakan pasar (Differentiated Marketing). Dengan strategi ini, perusahaan hanya

${ }^{16}$ Ibid., h. 292. 
melayani kebutuhan beberapa kelompok konsumen tertentu dengan jenis produk tertentu pula. Jadi, perusahaan atau produsen menawarkan berbagai variasi produk dan product mix yang disesuaikan dengan kebutuhan dan keinginan kelompok konsumen atau pembeli yang berbeda-beda, dengan program pemasaran yang tersendiri diharapkan dapat dicapai tingkat penjualan yang tinggi dalam masing-masing segmen pasar tersebut.

3) Strategi pemasaran yang terkonsentrasi (Concentrated Marketing). Dengan strategi ini, perusahaan mengkhususkan pemasaran produknya dalam beberapa segmen pasar, dengan pertimbangan keterbatasan sumber daya perusahaan produsen memilih segmen pasar tertentu dan menawarkan produk yang sesuai dengan kebutuhan dan keinginan kelompok konsumen yang ada pada segmen pasar itu, yang tentunya lebih spesifik.

\section{b. Strategi Bauran Pemasaran (Marketing Mix)}

Konsep pengembangan strategi pemasaran berkaitan dengan masalah bagaimana menetapkan bentuk penawaran pada segmen pasar tertentu. Hal ini dapat terpenuhi dengan penyediaan suatu sarana yang disebut marketing mix. Marketing mix ini merupakan inti dari sistem pemasaran perusahaan atau organisasi. Secara definisi dapat dikatakan bahwa Marketing mix adalah kombinasi dari empat variabel atau kegiatan yang merupakan inti dari sistem pemasaran perusahaan, yakni: produk, harga, kegiatan promosi, dan tempat.Kegiatan-kegiatan yang dimaksudkan dalam definisi tersebut adalah termasuk keputusan-keputusan dalam empat variabel, yaitu: produk, harga, promosi, dan tempat kegiatan-kegiatan ini perlu dikombinasi dan dikoordinasi agar perusahaan dapat melakukan tugas pemasaran seefektif mungkin. Jadi perusahaan atau organisasi tidak hanya sekedar memilih kombinasi yang terbaik saja, tetapi juga harus mengkoordinir berbagai macam elemen dari marketing mix tersebut untuk melaksanakan program pemasaran secara efektif. Berikut ini empat elemen pokok dalam marketing mix. ${ }^{17}$

\section{1) Produksi (Product) atau Jasa}

Produk atau jasa yang dibuat harus memperhatikan nilai kehalalan, bermutu, bermanfaat, dan berhubungan dengan kebutuhan kehidupan manusia. ${ }^{18}$ Melakukan jual beli yang mengandung unsur tidak jelas (gharar) terhadap suatu produk akan menimbulkan potensi terjadinya penipuan dan ketidakadilan terhadap salah satu pihak. Nabi Muhammad SAW melarang kita untuk melakukan transaksi terhadap suatu produk yang mengandung unsur gharar, sebagaimana hadisnya, "Rasulullah melarang jual beli gharar (yang tidak jelas produknya)" (HR. Muslim dari Abu Hurairah).Kualitas dari suatu produk harus menjadi perhatian utama dimana barang yang dijual harus jelas dan baik kualitasnya, agar calon pembeli dapat menilai dengan mudah terhadap produk tersebut. Rasulullah SAW melarang kepada kita untuk melakukan penipuan dengan cara memperlihatkan posisi produk yang baik dan menyembunyikan sisi kejelekan produk tersebut.

Dengan demikian, pengertian produk dalam ekonomi syariah haruslah memenuhi standarisasi mutu, berdaya guna, mudah dipakai, indah, dan memiliki daya tarik. Bukankah Allah menyukai suatu keindahan. ${ }^{19}$ Di dalam kondisi persaingan, sangat berbahaya bagi suatu perusahaan bila hanya mengandalkan produk yang ada tanpa usaha tertentu untuk mengembangkannya. Oleh karena itu, setiap perusahaan didalam mempertahankan dan meningkatkan penjualan dan share pasarnya, perlu mengadakan usaha menyempurnakan dan

${ }^{17}$ Ibid.,h. 65.

${ }^{18}$ Abdullah Amrin, Strategi Pemasaran Asuransi Syariah, (Jakarta: PT Grasindo, 2007), h. 59

\footnotetext{
${ }^{19}$ Ibid., h. 60.
} 
perubahan produk yang dihasilkan ke arah yang lebih baik, sehingga dapat memberikan daya guna dan daya pemuas serta daya tarik yang lebih besar. Strategi produk dalam hal ini adalah menetapkan cara dan penyediaan produk yang tepat bagi pasar yang dituju, sehingga dapat memuaskan para konsumennya dan sekaligus dapat meningkatkan keuntungan perusahaan dalam jangka panjang, melalui peningkatan penjualan dan peningkatan share pasar. Keputusan-keputusan tentang produk mencakup penentuan bentuk penawaran fisik, merknya, pembungkus, garansi dan service sesudah penjualan. Pengembangan produk dapat dilakukan setelah menganalisa kebutuhan dan keinginan pasarnya. Jika masalah ini telah diselesaikan, maka keputusan-keputusan tentang harga, distribusi dan promosi dapat diambil.

\section{2) Penentuan Harga}

Dalam ekonomi syariah didasarkan atas mekanisme pasar, yakni harga ditentukan berdasarkan kekuatan permintaan dan penawaran atas asas sukarela ('an taradhiin), sehingga tidak ada satu pihak pun yang teraniaya atau terzalimi. Dengan syarat, sebaiknya kedua belah pihak yang bertransaksi mengetahui produk dan harga di pasaran. Islam memperbolehkan ketentuan monopoli, duopoly, atau oligopoly dalam penentuan harga, selama ketentuan harga serta keuntungan yang diperoleh dari suatu produk merupakan keuntungan normal. Islam melarang praktik ikhtikar, yaitu mengambil keuntungan di atas keuntungan normal dengan jalan menjual lebih sedikit barang untuk harga yang lebih tinggi atau yang sering kita kenal dengan istilah monopoly's rentseeking. Sabda Rasulullah SAW, "Tidaklah orang melakukan ikhtikar atau kecuali ia berdosa" (HR. Muslim, Ahmad, dan Abu Dawud). Menurut hukum bertransaksi (Fiqh Muamalah), harga ditentukan atas dasar keadilan dengan proporsional, sebagaimana Firman Allah SWT dalam surat Al-Furqan: 67, "Dan orang-orang yang apabila membelanjakan hartanya, mereka tidak berlebih-lebihan, tidak pula kikir, dan adalah (pembelanjaan itu) di tengah-tengah antara yang sedemikian".

Nabi Muhammad SAW telah memberikan contoh bagaimana caranya menentukan suatu harga jual produk, sebagaimana beliau melakukan kegiatan perniagaan, yakni dengan cara menyebut berapa harga beli barang di Makkah, biaya transport dari Makkah ke Syam, dan lamanya memerlukan waktu sekian hari. Nabi Muhammad menyerahkan pembeli untuk menentukan harga yang pantas terhadap barang yang dijualnya. ${ }^{20}$ Harga merupakan satu-satunya unsur marketing mix yang menghasilkan penerimaan penjualan, sedangkan unsur lainya hanya unsur biaya saja. Walaupun penetapan harga merupakan persoalan penting, masih banyak perusahaan yang sempurna dalam menangani permasalahan penetapan harga tersebut. Karena menghasilkan penerimaan penjualan, tingkat keuntungan, serta share pasar yang dapat oleh perusahaan. Penetapan harga selalu menjadi masalah bagi setiap perusahaan karena penetapan harga ini bukanlah kekuasaan atau kewenangan yang mutlak dari seorang pengusaha. Seperti telah diutarakan di atas, dengan penetapan harga perusahaan dapat menciptakan hasil penerimaan penjualan dari produk yang dihasilkan dan dipasarkannya. ${ }^{21}$

\section{3) Tempat (Place)}

Penentuan tempat (place) yang mudah terjangkau dan terlihat akan memudahkan bagi konsumen untuk mengetahui, mengamati, dan memahami dari suatu produk atau jasa yang ditawarkan. Penentuan tempat didasarkan atas jenis usaha atau produk yang diciptakan.

\footnotetext{
${ }^{20}$ Ibid., h. 61 .

${ }^{21}$ Sofjan Assauri, ManajemenPemasaran, h.
} 197-248. 
Misalnya, untuk produk-produk sembako yang tidak tahan lama akan lebih baik jika di tempatkan dekat dengan keberadaan konsumen. Untuk barang-barang berharga dengan bermutu tinggi akan lebih baik dipasarkan di tempat yang berkesan mewah. Penempatan suatu produk atau jasa sangat mempengaruhi tingkatan harga, semakin representative suatu tempat maka berdampak akan semakin tinggi nilai suatu produk.

Ada tiga aspek pokok yang berkaitan dengan keputusan-keputusan tentang tempat atau distribusi. Aspek tersebut antara lain:

a). Sistem transportasi perusahaan

b). Sistem penyimpanan

c). Pemilihan saluran distribusi

Termasuk dalam usaha untuk mencapai tujuan dan sasaran perusahan di bidang pemasaran, setiap perusahaan melakukan kegiatan distribusi. Distibusi merupakan kegiatan penyampaian produk sampai ke tangan si pemakai atau konsumen pada waktu yang tepat. Oleh karena itu, kebijakan distribusi merupakan salah satu kebijakan pemasaran terpadu yang mencakup penentuan saluran pemasaran (marketing chanels) dan distribusi (physical distribution). ${ }^{22}$

Promosi

Promosi dalam sistem ekonomi syariah harus memperhatikan nilai-nilai kejujuran dan menjauhi penipuan. Media atau saran dan metode yang digunakan harus sesuai dengan syariah. Beberapa kelemahan promosi menurut Alex Schulz dalam buku The Marketing Game, yakni been there, done that; penyakit mengantuk; barang kecil tak bermutu (trinkets and trashitis). Been there, done that, yakni sebuah kondisi yang merasa puas dengan sistem promosi tahun lalu, kemudian sistem itu terus dipertahankan. Penyakit mengantuk, yakni terjadi karena lemahnya promosi yang dilakukan atau menjadi sangat membosankan bagi konsumen, sehingga konsumen pun mengantuk lantas

${ }^{22}$ Ibid., h. 197-248. tidur. Barang kecil dan tak bermutu (trinkets and trashitis), yakni penyakit yang sering ditemui dalam promosi adalah pemberian barang kecil dan tak bermutu. Konsumen masih dianggap sebagai anak kecil yang membutuhkan barang-barang pemberian. Memang, biaya produksi tidaklah besar, tetapi bisa dipastikan kerugian akan terjadi dengan metode promosi seperti ini. Termasuk dalam kegiatan promosi adalah: periklanan, personal selling, promosi penjualan, dan publisitas. Beberapa keputusan yang berkaitan dengan periklanan ini adalah pemilihan media (majalah, televisi, surat kabar, dan sebagainya), penentuan bentuk iklan dan beritanya, penarikan, pemilihan, latihan, kompensasi, dan supervisi merupakan tugas manajemen dalam kaitannya dengan salesman penjual. Promosi penjualan dengan menggunakan suatu pameran, peragaan, demonstrasi, contoh-contoh dan sebagainya. Sedangkan publisitas merupakan kegiatan yang hampir sama dengan periklanan, hanya dilakukan biasanya tanpa biaya. ${ }^{23}$

\section{c. Faktor-faktor yang Mempengaruhi Strategi Pemasaran}

Pada umumnya kegiatan pemasaran berkaitan dengan koordinasi beberapa kegiatan bisnis. Strategi pemasaran ini dipengaruhi oleh: Faktor mikro, yaitu perantara pemasaran, pemasok, pesaing dan masyarakat

1) Faktor makro, yaitu demografi/ ekonomi, politik/hukum, teknologi/ fisik dan sosial/budaya.

Adapun beberapa faktor lain yang menjadi penghambat kesesuaian strategi pemasaran, diantaranya adalah:

a) Sumber Daya Manusia. Sumber daya manusia sering disebut sebagai Human Resource, tentang atau kekuatan manusia (energi dan power). Sumber daya juga

${ }^{23}$ Ibid.,h. 249. 
yang juga disebut sumber tenaga, kemampuan, kekuatan, keahlian yang dimiliki oleh manusia, dipunyai juga oleh makhluk organisme lainnya. Manusia sebagai perencanaan, pelaksana pengendali, dan evaluasi suatu pembangunan dan nikmati hasil evaluasi tersebut sangat mempengaruhi keberhasilan pembangunan karena manusia mempunyai peran yang sangat menentukan. $^{24}$

b) Modal. Modal merupakan faktor yang amat penting bagi perkembangan dan kemajuan bank sekaligus menjaga kepercayaan masyarakat. Setiap penciptaan aktiva, disamping berpotensi menghasilkan keuntungan juga berpotensi menimbulkan terjadinya risiko. Oleh karena itu modal juga harus dapat digunakan untuk menjaga kemungkinan terjadinya risiko kerugian atas aktiva dan investasi pada aktiva, terutama yang berasal dari dana-dana pihak ketiga atau masyarakat. Peningkatan peran aktiva sebagai penghasil keuntungan harus secara simultan dibarengi dengan pertimbangan risiko yang mungkin timbul guna melindungi kepentingan para pemilik dana. Jika bank tersebut sudah beroperasi maka modal merupakan salah satu faktor yang sangat penting bagi pengembangan usaha dan menampung risiko kerugian. Menurut Zainul Arifin, modal didefinisikan sebagai sesuatu yang mewakili kepentingan pemilik dalam suatu perusahaan. ${ }^{25}$

c) Regulasi atau Undang-undang. Koperasi dan BMT mempunyai pegangan hukum yang sama, yaitu Undang-undang tentang perkoperasian karena hingga saat ini BMT belum diatur undang-undang tersendiri. BMT atau Baitul Ma wa Tamwil adalah salah satu dari lembaga keuangan syariah atau LKS. Untuk itu hingga saat ini BMT dibawah pembinaan kementerian koperasi dengan berpedoman pada undang-undang

${ }^{24}$ Aburrahman Fathoni, Manajemen Sumber Daya Manusia, Cet. Ke-1 (Jakarta: PT Renika Cipta, 2006).

${ }^{25}$ Zainul Arifin, Dasar-Dasar Manajemen Perbankan Syariah, (Jakarta: Alfabeta, 2002), hal. 15. tentang perkoperasian. Undang-undang Republik Indonesia No. 25 Tahun 1992 tentang perkoperasian yakni, koperasi adalah Badan Usaha yang beranggotakan orang-seorang atau Badan hukum koperasi dengan melandaskan kegiatannya berdasarkan prinsip koperasi sekaligus sebagai gerakan ekonomi rakyat yang berdasar atas asas kekeluargaan.

\section{2) Maqashid Syariah dalam Pandangan Fuqaha}

a) Pengertian Maqashid Syariah

Secara etimologi Maqashid al-Syari'ah terdiri dari dua kata, yakni maqashid dan syari'ah. Maqashid adalah bentuk jamak dari maqshud yang berarti kesengajaan, atau tujuan. Adapun syari'ah artinya menuju air, atau bisa dikatakan dengan jalan menuju ke arah sumber kehidupan. Maqashid al-Syari'ah adalah sejumlah makna atau sasaran yang hendak dicapai oleh syara' dalam semua atau sebagian besar kasus hukumnya, atau ia adalah tujuan dari syari'ah, atau rahasia di balik pencanangan tiap-tiap hukum oleh syar'i (pemegang otoritas syari'ah, Allah dan RasulNya). ${ }^{26}$ Ibn al-Qayyim al-Jauziah menegaskan bahwa syari'ah itu berdasarkan kepada hikmah-hikmah dan maslahah-maslahah untuk manusia baik di dunia maupun di akhirat. Perubahan hukum yang berlaku berdasarkan perubahan zaman dan tempat adalah untuk menjamin syari'ah dapat mendatangkan kemaslahatan kepada manusia. ${ }^{27}$

Adapun secara terminologi, beberapa pengertian tentang maqashid al-syari'ah yang dikemukakan oleh beberapa ulama terdahulu antara lain:

a. Al-Imam al-Ghazali: "Penjagaan terhadap maksud dan tujuan syari'ah adalah upaya mendasar untuk bertahan hidup, menahan faktor-faktor kerusakan dan mendorong terjadinya kesejahteraan". ${ }^{28}$

\footnotetext{
${ }^{26}$ Wahbah al-Zuhayli, Ushul al-Fiqh alIslami, (Damaskus: Dar al-Fikr, 1998), Juz II, 1045.

${ }^{27}$ Ibn Qayyim al-Jauziah, I'lam alMuwaqqi'in, (Beirut: Dar al-Kutub al-'Ilmiah, 1996), Jilid III, 37.

${ }^{28}$ Al-Ghazali, Shifa al-Ghalil, Tahqiq Hamdi Ubaid al-Kabisi, (Baghdad: Mathba'ah al-Irshad, 1971) 159. Lihat juga Bin Zaghibah Izz al-Din, $A l$ -
} 
b. Al-Imam al-Syathibi: "Al-Maqashid terbagi menjadi dua: yang pertama, berkaitan dengan maksud Tuhan selaku pembuatan syari'ah dan kedua, berkaitan dengan maksud mukallaf". ${ }^{29}$ Kembali kepada maksud Syar'i (Allah) adalah kemaslahatan untuk hamba-Nya di dalam dua tempat dunia dan akhirat. Dan kembali kepada maksud mukallaf (manusia) adalah ketika hamba-Nya dianjurkan untuk hidup dalam kemaslahatan di dunia dan akhirat. Yaitu, dengan menghindari kerusakankerusakan yang ada di dalam dunia. Maka dari itu, haruslah ada penjelasan antara kemaslahatan (mashlahah) dan kerusakan (mafsadah) ${ }^{30}$

c. 'Alal al-Fasi: "Maqashid al-Syari'ah merupakan tujuan pokok syari'ah dan rahasia dari setiap hukum yang ditetapkan oleh Tuhan". ${ }^{31}$

d. Ahmad al-Raysuni: "Maqashid al-Syari'ah merupakan tujuan-tujuan yang telah ditetapkan oleh syari'ah untuk dicapai demi kemaslahatan manusia". ${ }^{32}$

e. Abdul Wahab Khallaf:

"Tujuan umum ketika Allah menetapkan hukum-hukum-Nya adalah untuk mewujudkan kemaslahatan manusia dengan terpenuhinya kebutuhan yang dharuriyah, hajiyah, dan tahsiniyah". ${ }^{33}$ Dari beberapa pengertian di atas, istilah Maqashid Syariah dipopulerkan oleh Abu Ishaq asy-Syatibi yang tertuang dalam karyanya al-Muwafaqat, sebagaimana

Maqashid al-Ammah li al-Syari'ah al-Islamiyah (Kairo: Dar al-Shafwah li al-Thaba'ah wa al-Nasyr wa al-Tauzi', 1996) 40.

${ }^{29}$ Al-Syathibi, Al-Muwafaqat fi Ushul alSyari'ah, (Beirut: Dar al-Ma'rifah, t.th), 322.

${ }^{30}$ Jamal al-Din 'Athiyyah, Al-Nadzariyah al'Ammah li al-Syari'ah al-Islamiyah, (t.t: 1988), 102.

${ }^{31}$ Izz al-Din, Al-Maqashid al-Ammah, 44.

${ }^{32}$ Ahmad al-Raysuni, Nadzariyah alMaqashid Inda al-Imam al-Syathibi, (Beirut: AlMa'had al-'Ali li al-Fikr al-Islami, al-Muassasah al-Jami’iyah li al-Dirasat wa al-Nashr wa al-Tawzi, t.th.), 45.

${ }^{33}$ Abdul Wahhab Khallaf, 'Ilmu Ushul Fiqh, (Kuwait: Dar al-Qalam li al-Nashr wa al-Tawzi', 1990), 197. dalam ungkapan adalah "Sesungguhnya Syariah itu diturunkan untuk merealisasikan maksud Allah dalam mewujudkan kemaslahatan agama dan dunia secara bersama". Maqashid alSyariah ialah tujuan al-Syar'i (Allah SWT dan Rasulullah SAW) dalam menetapkan hukum Islam. Tujuan tersebut dapat ditelusuri dari nash Al-Qur'an dan Sunnah Rasulullah SAW, sebagai alasan logis bagi rumusan suatu hukum yang berorientasi kepada kemaslahatan umat manusia.

\section{b) Konsep Maqashid Al-Syariah Dharuriat Al-Kulliat Al-Khams)}

Guna memperoleh gambaran yang utuh tentang maqashid al-syariah, berikut akan dijelaskan kelima pokok kemaslahatan dengan peringkatnya masing-masing:

\section{a. Memelihara atau Melindungi Agama (Hifzh Al-Din)}

Memelihara agama merupakan tujuan pertama hukum Islam. Ini karena agama merupakan pedoman hidup manusia, dan dalam agama Islam selain komponenkomponen akidah yang merupakan sikap hidup seorang Muslim, terdapat juga syariah yang merupakan sikap hidup seorang Muslim baik dalam berhubungan dengan Tuhannya, maupun dalam berhubungan dengan manusia lain dan benda dalam masyarakat. Karena itulah, hukum Islam wajib melindungi agama yang dianut oleh seseorang dan menjamin kemerdekaan setiap orang untuk beribadah menurut keyakinannya.

Syariat Islam (Al-Qur'an) menolak segala bentuk pemaksaan, karena sesorang memeluk Islam, diberi petunjuk oleh Allah. Allah yang akan membukakan dan menerangi mata hatinya, kemudian seseorang tersebut akan masuk Islam dengan bukti dan hujjah. Barangsiapa yang hatinya dibutakan, pendengaran, dan penglihatannya ditutup oleh Allah, maka tidak ada gunanya mereka masuk Islam dalam keadaan dipaksa. 


\section{b. Memelihara atau Melindungi Jiwa (Hifzh Al-Nafs)}

Memelihara atau melindungi jiwa adalah tujuan yang kedua hukum Islam. Untuk tujuan ini, Islam melarang penghilangan jiwa (pembunuhan) dan terhadap pelaku penghilangan jiwa (pembunuhan) diancam dengan hukuman qishash (pembalasan yang seimbang), sehingga dengan demikian diharapkan agar orang sebelum melakukan pembunuhan, berpikir panjang karena apabila orang yang dibunuh itu mati, maka si pembunuh juga akan mati atau jika orang yang dibunuh itu tidak mati tetapi hanya cedera, maka si pelakunya juga akan cedera.

Pada tanggal 9 Dzulhijjah tahun 10 $\mathrm{H}$, Nabi SAW menuju ke Padang Arafah, disana ia berkhotbah, yang intinya bahwa Islam adalah risalah langit yang terakhir, sejak empat belas abad yang lalu telah mensyariatkan (mengatur) hak-hak asasi manusia secara komprehensif dan mendalam. Islam mengaturnya dengan segala macam jaminan yang cukup untuk menjaga hak-hak tersebut. Islam membentuk masyarakatnya di atas fondasi dan dasar yang menguatkan dan memperkukuh hak-hak asasi manusia.

\section{c. Memelihara atau Melindungi Akal (Hifzh Al-'Aql) \\ Manusia adalah salah satu makhluk} Allah SWT yang paling sempurna. Artinya, bahwa selain manusia ada makhluk lainnya di luar manusia. Walaupun demikian, ada dua hal yang membedakan manusia dengan makhluk lain. Pertama, Allah SWT telah menjadikan manusia dalam bentuk yang paling baik, dibandingkan dengan bentuk makhluk-makhluk lainnya. Akan tetapi, bentuk yang indah itu tidak ada gunanya, kalau tidak ada hal yang kedua, yaitu akal.

Akal merupakan sumber hikmah (pengetahuan), sinar hidayah dan media kebahagiaan manusia di dunia dan akhirat.
Dengan akal, surat perintah dari Allah disampaikan, dengannya pula manusia berhak menjadi pemimpin di muka bumi, dan dengannya manusia menjadi sempurna, mulia, dan berbeda dengan makhluk lainnya. Karena itulah, akal paling penting dalam pandangan Islam. Allah pun selalu memuji orang yang berakal. Berdasarkan pentingnya akal bagi kehidupan manusia, maka pemeliharaan dan perlindungan akal menjadi tujuan syari'ah yang sangat penting dalam Islam.

\section{d. Memelihara atau Melindungi Keturunan (Hifzh Al-Nasb) \\ Perlindungan Islam terhadap} keturunan adalah dengan mensyariatkannya pernikahan dan mengharamkan zina, menetapkan siapa-siapa yang tidak boleh dikawini, bagaimana cara-cara perkawinan itu dilakukan dan syarat-syarat apa yang harus dipenuhi, sehingga perkawinan itu dianggap sah dan pencampuran antara dua manusia yang berlainan jenis itu dianggap sah dan menjadi keturunan sah dari ayahnya. Islam bahkan tidak hanya melarang zina saja tetapi juga melarang hal-hal yang dapat membawa kepada zina. Islam juga memberikan jalan bagi laki-laki yang berkehendak untuk menikahi wanita lebih dari satu untuk menjaga agar dirinya tidak terjerumus ke lembah perzinahan. Hukum kekeluargaan dan kewarisan Islam adalah hukum-hukum yang secara khusus diciptakan Allah untuk memelihara kemurnian darah dan kemaslahatan keturunan. Dalam hubungan ini, perlu dicatat bahwa dalam hukum Islam ini diatur lebih perinci dan pasti dibandingkan dengan ayat-ayat hukum lainnya. Maksudnya adalah agar pemeliharaan dan kelanjutan dapat berlangsung dengan sebaik-baiknya. $^{34}$

\footnotetext{
${ }^{34}$ Saifudin Zuhri, Ushul Fikih: Akal sebagai Sumber Hukum Islam, (Yogyakarta: Pustaka Pelajar, 2009), 64.
} 


\section{e. Memelihara atau Melindungi Harta Benda (Hifzh Al-Maal)}

Harta merupakan salah satu yang dibutuhkan dalam kehidupan ini. Sebagai sebuah kebutuhan, maka harta menurut pandangan Islam harus dicari dan didapatkan. Karena harta merupakan sebuah kebutuhan, maka manusia juga termotivasi untuk mencari harta demi menjaga eksistensinya dan demi menambah kenikmatan materi dan religi, dia tidak boleh berdiri sebagai penghalang antar dirinya dengan harta. Namun, semua motivasi ini dibatasi dengan tiga syarat, yaitu harta yang dikumpulkannya dengan cara yang halal, digunakan untuk hal-hal yang halal, dan dari harta ini harus dikeluarkan hak Allah dan manusia lainnya. Istilah harta atau al-maal dalam Al-Qur'an maupun Hadist tidak dibatasi dalam ruang lingkup makna tertentu, sehingga pengertian al-maal sangat luas dan selalu berkembang. Kriteria harta menurut para ahli fikih terdiri atas: pertama, memiliki unsur nilai ekonomis; kedua, unsur manfaat atau jasa yang diperoleh dari suatu barang. Al-Qur'an mempunyai pandangannya tersendiri terhadap amanah Allah SWT yang bernama harta ini dengan menerangkannya secara jelas melalui nashsh-nashshnya sebagai peringatan dan pedoman demi untuk mencapai kebahagiaan di dunia dan juga di akhirat. Harta menurut kacamata Islam merujuk kepada nashsh-nashsh AlQur'an yang menggariskan dasar-dasar pokok tentang harta yaitu bahwa pencipta dan pemilik harta yang hakiki Allah SWT.

\section{Metode Penelitian}

1. Pendekatan dan Jenis Penelitian

a. Pendekatan Penelitian

Metode penelitian ini pada dasarnya merupakan cara ilmiah untuk mendapatkan data dengan tujuan dan kegunaan tertentu, secara umum data yang telah diperoleh dari peneliti dapat digunakan untuk memahami, memecahkan dan mengantisipasi masalah. Pendekatan ini bertujuan untuk menjelaskan dan memahami makna dari fakta-fakta yang diteliti, serta memudahkan penulis untuk lebih mengamati sejauh mana kesesuaian strategi pemasaran terhadap maqashid syariah di Koperasi Syariah BMT BISMA (Bina Insan Sejahtera Mandiri).

\section{b. Jenis Penelitian}

Jenis penelitian yang digunakan adalah penelitian deskriptif kualitatif. Metode penelitian deskriptif kualitatif adalah suatu metode yang digunakan untuk menemukan pengetahuan terhadap subyek penelitian pada suatu saat nanti.

\section{Tempat dan Waktu Penelitian Tempat Penelitian}

Penelitian ini dilakukan di Koperasi Syariah BMT BISMA (Bina Insan Sejahtera Mandiri). Dengan proses penelitian di Koperasi Syariah BMT BISMA Kabupaten Tangerang, Banten.

\section{Sumber dan Jenis Data Penelitian a. Sumber Data}

Untuk sumber data dalam penelitian ini, penulis memilih Koperasi Syariah BMT BISMA Cabang Kelapa Dua Kabupaten Tangerang, Karyawan (Account Officer) dan Nasabah/Anggota Koperasi Syariah BMT BISMA Cabang Kelapa Dua Kabupaten Tangerang, bukubuku, artikel, jurnal, dan yang lain sebagainya.

\section{b. Jenis Data}

Untuk mengumpulkan data penelitian ini penulis membagi data ke dalam beberapa hal:

1). Data Primer, merupakan data utama yang diperoleh dari Koperasi Syariah BMT BISMA (Bina Insan Sejahtera Mandiri) Kantor Cabang Kelapa Dua Kabupaten Tangerang Banten. 
2). Data Sekunder, merupakan data yang diperoleh dari berbagai buku, dokumentasi pada Koperasi Syariah BMT BISMA (Bina Insan Sejahtera Mandiri) Kantor Cabang Kelapa Dua Kabupaten Tangerang Banten yang berkaitan dengan penelitian.

\section{Teknik Pengambilan Data}

Dalam melakukan penelitian, penulis menggunakan teknik:

a. Studi Kepustakaan (Library Research)

Dalam penelitian ini penulis memproleh data dengan mempelajari bahan bacaan seperti buku, artikel, jurnal, dan lain-lain yang berhubungan dengan masalah yang akan penulis teliti.

b. Studi Lapangan (Field Research)

Dalam penelitian ini dilakukan dengan mengunjungi langsung objek penelitian dalam rangka pengumpulan data-data baik yang bersifat kualitatif maupun kuantitatif, dengan ini penulis memperoleh data dengan melakukan wawancara terbuka dan observasi yaitu dengan alat rekaman dan lain-lain yang berhubungan dengan penelitian. Dalam penelitian lapangan ini digunakan beberapa teknik pengumpulan data, yaitu:

1) Wawancara (interview), yaitu suatu cara pengumpulan data untuk memperoleh informasi langsung dari sumbernya dan dilakukan dengan pihak yang memiliki keterkaitan dengan masalah yang hendak diteliti.

2) Pengamatan (observation), yaitu suatu cara pengumpulan data dengan cara melakukan pengamatan langsung ke objek penelitian.

3) Dokumentasi, yaitu suatu cara pengumpulan data untuk memperoleh data langsung dari objek penelitian, meliputi laporan perusahaan, foto-foto, film documenter, dan data-data lainnya yang relevan dengan penelitian.
D. Hasil Penelitian Dan Pembahasan

1. Temuan Penelitian

a. Sejarah Berdirinya BMT BISMA

Dari informasi yang penyusun teliti di BMT BISMA, penyusun menemukan bahwa perusahaan BMT BISMA ini memiliki nilai-nilai perusahaan yang menjunjung tinggi kemanusiaan dan integritas telah tertanam kuat pada segenap insan BMT BISMA sejak awal pendiriannya. BMT BISMA ini diinisiasi pada bulan Juni 2011 oleh inisiator: Bapak H. Moh. Bonnie Mufidjar, Bapak H. Sumanto dan Drs. Fajruddin Malik dengan skema kerjasama dengan BMT KAS di tangani langsung oleh Sdr. Fajruddin Malik (Praktisi BMT dan Ketua Pengurus BMT KAS) dengan pola kantor cabang otonom.

Pendirian BMT BISMA dilatarbelakangi oleh keprihatinan melihat fenomena yang terjadi di masyarakat akan sulitnya para pengusaha kecil mikro, ekonomi lemah dalam akses permodalan dan sulitnya meningkatkan kualitas hidup menuju sejahtera yang di Ridhoi Allah SWT. Terkumpul modal awal berupa simpanan penyertaan dari anggota pendiri 5 orang sebesar Rp. 52.500.000,00.

Dalam perjalanannya mengalami banyak kendala pada likuiditas dana penyaluran, bulan keempat sampai dengan bulan kedelapan BMT mendapatkan kepercayaan untuk mengelola simpanan berjangka sebesar Rp. 200.000.000,00. Selama tahun 2012 sampai dengan 2014 BMT BISMA mengalami degradasi organisasi namun tidak mengurangi semangat dan loyalitas pengelola. Alhamdulillah Yayasan Rahmatan lil Alamiin yang dikomandoi oleh Bapak $\mathrm{H}$. Widoyo bergabung di BMT BISMA sehingga berdampak positif baik pada sumber daya manusia (SDM) maupun keuangan BMT saat ini. Terlihat dari penambahan SDM Tahun 2016 berjumlah 18 orang. Disaat kondisi secara makro ekonomi bangsa kita terpuruk, otomatis telah memukul pertumbuhan usaha di negara kita yang berdampak kontra 
produktif bagi kesejahteraan masyarakat. Disini lah kita lihat ketahanan ekonomi mikro lebih teruji dibanding usaha-usaha besar yang gulung tikar. Berdasarkan data, jumlah sektor Usaha Mikro dan Kecil (UMK) saat ini mencapai 45 juta lebih atau sekitar $99,5 \%$ dari total unit usaha yang ada di Indonesia. Artinya bila sektor UMK ini berkembang maka kesejahteraan masyarakat itu akan meningkat dengan baik. Namun sayangnya kondisi para pengusaha mikro dan kecil ini banyak yang terjerat dengan rentenir, karena akses permodalan sanga sulit mereka dapatkan dari perbankan. Oleh karena itulah BMT BISMA tergerak untuk berperan aktif mencoba menjadi bagian dari solusi bagi problem sosial ekonomi masyarakat kecil, yang konsen pada permodalan pengusaha mikro dan kecil disertai pendampingan dan bimbingan menajemen. Dengan demikian diharapkan kesejahteraan dan keadilan ekonomi dapat terwujud dan dirasakan oleh masyarakat Indonesia. Disamping itu, usaha ini merupakan upaya nyata untuk menyebarkan nilai-nilai profetik dengan mensyiarkan dakwah Islam yang merupakan tuntunan dari Firman Allah AlQur'an surat Al-Maidah (5): 2:

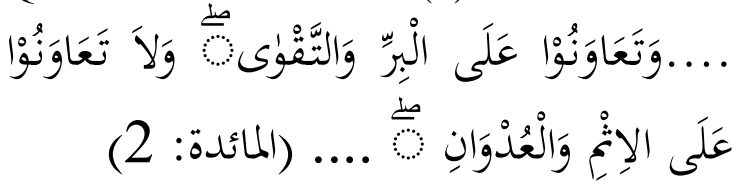

....Dan tolong-menolonglah kamu dalam (mengerjakan) kebajikan dan takwa, dan jangan tolong-menolong dalam berbuat dosa dan permusuhan. Bertakwalah kepada Allah, sungguh, Allah sangat berat siksaan-Nya.... (QS. Al-Maidah: 2)

\section{b. Visi dan Misi BMT BISMA \\ 1) Visi}

"Menjadi Koperasi Syariah yang sehat dan unggul di Provinsi Banten dengan perumbuhan asset mencapai $30 \mathrm{M}$ di tahun 2030".
2) Misi

a) Mempersiapkan SOP dan sistem keuangan yang efektif dan aplikatif sesuai prinsip Syariah

b) Melakukan promosi dan pembinaan yang efektif kepada masyarakat Banten

c) Meningkatkan Sumber Daya Insani yang handal

\section{Langkah-langkah Memasarkan Produk BMT BISMA}

Perkembangan BMT saat ini patut kita syukuri, karena dapat dilihat semakin banyak masyarakat yang melakukan transaksi melalui BMT. Namun pertumbuhan ini tidak hanya dapat dilihat dari tingginya minat masyarakat. Melihat dari tingginya minat masyarakat terhadap BMT, maka BMT harus menyikapi dengan baik. Oleh karenanya BMT dapat melakukan pengenalan produk-produk yang ditawarkan sehingga memiliki daya tarik kepada nasabah maupun calon nasabah untuk mengetahui lebih lanjut tentang produk-produk BMT. ${ }^{35}$

Menyikapi semakin berkembangnya BMT saat ini, khususnya BMT BISMA maka BMT BISMA memiliki langkahlangkah atau proses produk-produknya agar dapat lebih dikenal dan dipahami oleh masyarakat sekitar. Adapun langkahlangkah atau metode marketing, dimana metode marketing yaitu proses pengenalan atau proses pemasyarakatan. Langkahlangkah atau metode sosialisasi tersebut didukung oleh berbagai faktor, yaitu:

\section{a. Pelanggan atau Anggota/Nasabah}

Pelanggan atau nasabah adalah umat Islam yang tersadar akan tuntunan agama. Namun, belum semua pelanggan atau nasabah yang mengetahui banyak tentang seluk beluk BMT BISMA. Meskipun demikain, BMT tetap menanamkan

${ }^{35}$ Wawancara Pribadi dengan Didi Sudiarto, Tangerang: Koperasi Syariah BMT Bisma, Kamis 18 Juli 2019. 
kepercayaan terhadap pelangan atau nasabahnya.

\section{b. Produk atau Jasa}

Dalam hal produk, BMT memberikan produk yang menguntungkan nasabahnya, produk BMT selalu inovatif yang tidak sama dengan produk-produk Konvensional. Selain produk BMT BISMA pun menawarkan jasa yang meliputi pembayaran PLN, TELKOM, dan PAM

\section{c. Pembayaran tagihan seluler pasca bayar}

1) Isi ulang pulsa

Dalam hal ini, BMT BISMA memberikan jasa yang ditawarkan pada setiap hari kerja.

2) Pasar

Segmen pasar BMT BISMA memang kalangan menengah kebawah yang ditargetkan kepada para pedagang, dan bagi mereka yang kurang mengetahui bagaimana cara bertransaksi dengan BMT, BMT memfasilitasi hal tersebut untuk memuaskan konsumen untuk mendapatkan pangsa pasar yang luas.

3) Teknologi

Dalam memasarkan produk, BMT BISMA menggunakan media elektronik maupun media cetak. Media yang digunakan seperti internet, facebook, dan instagram ditampilkan secara detail mulai dengan produk-produknya dalam situs tersebut. BMT BISMA mengenalkan visi dan misi dan dalam situs tersebut juga disediakan kolom tanya jawab dan konsultasi. Selain dari media sosial BMT BISMA melakukan promosi melalui media cetak seperti brosur dan juga spanduk.

4) Komitmen terhadap pertumbuhan, keuntungan dan stabilitas

BMT BISMA memegang teguh pendirian dengan memberikan inovasi terhadap produk-produk yang telah dikeluarkan. Apabila produk yang yang diluncurkan dipasarkan telah ada duplikasinya, maka BMT BISMA akan melakukan investasi dan meluncurkan produk barunya.

5) Konsep Perusahaan

BMT BISMA memiliki konsep perusahaan yang jelas, yakni menanamkan kesadaran akan tuntunan agama dalam bertransaksi secara syariah yang tidak menyimpang konsep syariah.

6) Komitmen terhadap image masyarakat. Image masyarakat tentang BMT BISMA adalah seluruh lembaga keuangan mikro syariah yang secara konsisten memberikan pembiayaan yang berdasarkan syariah.

7) Komitmen terhadap karyawan. Seluruh karyawan di BMT BISMA keseluruhannya beragama Islam, memiliki ideologi serta kebersamaan untuk memajukan BMT BISMA. Seperti pada bagian marketing dituntut mengkoordinasikan hubungan kerjasama serta menjaga hubungan baik dengan pelanggan atau nasabah.

\section{E. Pembahasan Hasil Penelitian}

\section{Strategi Pemasaran Koperasi} Syariah BMT BISMA

Sesuai dengan visinya "Menjadi Koperasi Syariah yang sehat dan unggul di Provinsi Banten". Maka salah satu kunci terpenting bagi BMT BISMA untuk mewujudkan visi tersebut adalah dengan marketing. Sebagai salah satu modal perusahaan, BMT BISMA berupaya melakukan perbaikan-perbaikan yang berkesinambungan guna untuk mengembangkan kualitas produk-produknya. Adapun upaya-upaya yang dilakukan BMT BISMA dalam proses pemasaran produk kepada masyarakat, yaitu memanfaatkan media yang ada berupa brosur, spanduk merupakan media yang tepat untuk melakukan proses strategi sosialisasi karena spanduk mudah dijangkau oleh masyarakat, selain itu biaya yang 
dikeluarkan cukup murah dan lebih efektif. Sedangkan internet merupakan media pemasaran yang lengkap dimana media ini dapat memudahkan nasabah/ anggota atau calon nasabah/anggota dalam melakukan transaksi. Namun BMT BISMA lebih tertuju kepada brosur dan spanduk, karena pemasangan spanduk ditempat-tempat strategis diyakini merupakan target pasar yang tepat. Selain pelaksanaan yang strategis namun biayanya juga relatif murah dan terjangkau juga lebih mengena kepada masyarakat.

\section{Strategi Produk (Product)}

Produk merupakan segala sesuatu yang dapat ditawarkan untuk diperhatikan, diminta, dicari, dibeli, digunakan, dan atau dikonsumsi pasar sebagai pemenuhan kebutuhan atau keinginan pasar bersangkutan. Berdasarkan perspektif nasabah/anggota, produk adalah segala sesuatu yang diterima pelanggan dari sebuah pertukaran dengan pemasar. Produk mencakup berbagai macam tipe, diantaranya barang fisik (seperti mobil, smartphone, televisi, sepatu, arloji), jasa (universitas, restoran, hotel, rumah sakit). Jadi produk bisa berupa manfaat tangible maupun intangible yang berpotensi memuaskan pelanggan. ${ }^{36}$

Dalam menerapkan strategi pemasaran produknya, BMT BISMA menjalankan prinsip-prinsip yang sesuai dengan syariah, yaitu: Tidak menjual produk yang mengandung unsur haram (seperti alkohol, buku porno, dll), Uang yang diinvestasikan dalam setiap produk diinvestasikan pada sektor yang bebas haram, dan menyalurkan uang yang diinvestasikan sesuai dengan kebutuhan. ${ }^{37}$ Strategi Promosi (Promotion)

\footnotetext{
${ }^{36}$ Tjiptono, Strategi Pemasaran, h. 230.

${ }^{37}$ Wawancara Pribadi dengan Budi Susanto, Tangerang: Koperasi Syariah BMT Bisma, Kamis 18 Juli 2019.
}

Promosi merupakan kegiatan marketing mix yang terakhir serta inilah yang paling sering diidentikan sebagai akivitas pemasaran dalam arti sempit. Promosi merupakan sarana paling ampuh untuk menarik dan mempertahankan nasabahnya. Salah satu tujuan promosi BMT adalah menginformasikan segala jenis produk yang ditawarkan dan berusaha menarik calon nasabah lain. Kemudian promosi juga berfungsi mengingatkan nasabah akan produk, promosi juga ikut mempengaruhi nasabah untuk membeli dan akhirnya promosi juga akan meningkatkan citra BMT dimata para nasabahnya. ${ }^{38}$

Adapun kegiatan promosi yang diterapkan oleh BMT BISMA adalah sebagai berikut:

Melalui brosur, brosur yang didalamnya berisikan tentang profil BMT BISMA, produk-produk yang disediakan, visi dan misi, layanan yang disediakan. Kemudian dalam brosur ini didesain sedemikan rupa untuk menarik para nasabah/anggota dengan memberikan warna yang menarik, logo sebagai simbol ataupun lambang yang mudah dipahami oleh orang lain, serta isi singkat dalam brosur mengenai BMT BISMA.

Melalui media sosial bertujuan untuk menjalin hubungan dan membuka selebarlebarnya para anggota melalui akun media sosial, dengan media sosial nasabah/ anggota mendapatkan informasi tentang BMT BISMA yang lebih mendalam setelah mendapat informasi secara umum yang diperoleh dari brosur. Pembuatan media sosial ini diharapkan agar nasabah/ anggota dapat mengakses informasi

\footnotetext{
${ }^{38} \mathrm{Al}$ Arif, Dasar-dasar Pemasaran Bank Syariah, h. 169-170.

${ }^{39}$ Wawancara Pribadi dengan Didi Sudiarto, Tangerang: Koperasi Syariah BMT Bisma, Kamis 18 Juli 2019.
} 
tentang BMT BISMA dengan mudah dimanapun dan kapanpun. ${ }^{40}$

Dalam promosi langsung, BMT Bisma melakukan presentasi dibeberapa sekolahsekolah, dengan rekan bisnis, maupun lingkungan keluarga. ${ }^{41}$

\section{Strategi Tempat (Place)}

Untuk memberikan kemudahan nasabah/anggota, BMT BISMA melakukan memindahkan lokasinya dari yang sebelumnya kurang strategi, yaitu sebelumnya bertempat di Jl. Bidar Kelapa Dua Kab. Tangerang, kemudian berpindah tempat Jl. Layar 1 No. 37 Kelapa Dua Kab. Tangerang Banten. Perpindahan yang dilakukan ini merupakan suatu hal yang baik dalam strategi pemasaran BMT BISMA. Karena lokasi ini terletak dipinggir jalan yang sering dilewati orang dan merupakan jalur utama, kemungkinan perpindahan lokasi ini diharapkan secara sekilas masyarakat sekitar kelapa dua dapat mengetahui keberadaan BMT BISMA ${ }^{42}$

\section{F. Penutup}

\section{Kesimpulan}

Berdasarkan pada pembahasan yang telah diuraikan diatas tentang strategi pemasaran telah sesuai dengan prinsip maqashid syariah yang diterapkan Koperasi Syariah BMT BISMA, dengan hal ini dapat diketahui sebagai berikut:

a. Strategi pemasaran yang diterapkan BMT BISMA dalam memasarkan produk melalui media yang ada seperti, brosur, spanduk, dan media sosial dianggap cukup efektif. Selain itu

\footnotetext{
${ }^{40}$ Wawancara Pribadi dengan Ibnu Khanun, Tangerang: Koperasi Syariah BMT Bisma, Kamis 18 Juli 2019.

${ }^{41}$ Wawancara Pribadi dengan Budi Susanto, Tangerang: Koperasi Syariah BMT Bisma, Kamis 18 Juli 2019

${ }^{42}$ Wawancara Pribadi dengan Fardi Indra Ramadhani, Tangerang: Koperasi Syariah BMT Bisma, Kamis 18 Juli 2019.
}

BMT BISMA juga berusaha untuk memasarkan produk-produknya melalui sektor perdagangan dan dalam promosi langsung, BMT BISMA melakukan presentasi dibeberapa sekolah-sekolah, dengan rekan bisnis, maupun lingkungan keluarga strategi yang digunakan BMT BISMA melalui strategi pemasaran yaitu layanan yang diberikan kepada nasabah/anggota melalui pemberitahun secara langsung yaitu dengan bertatap muka, dengan jemput bola yang bertujuan untuk melayani nasabah/ anggota yang khususnya pedagang yang sibuk dengan pekerjaannya sehingga kewajiban nasabah/anggota dapat terpenuhi dengan baik.

b. Bahwa BMT BISMA menerapkan karakteristik pemasaran berdasarkan maqashid syariah yang terdiri dari beberapa unsur yaitu teitis, etis, realistis, dan humanistis. Penerapan karakter teitis adalah pandangan dasar tentang bekerja sebagai ibadah. Penerapan karakter etis adalah bagaimana seorang marketing dalam berkakhlaq dan moral. Penerapan karakter realistis adalah bersikap professional kepada nasabah/anggota tanpa mendeskriminasi. Penerapan karakter humanistis adalah dengan membantu sesama dengan melakukan kegiatan sosial, dari keempat penerapan karakteristik di BMT BISMA mengandung nilai-nilai syariah (maqashid syariah). Nilai itu dalam syariah adalah menerapkan sesuai dengan 5 lingkup maqashid syariah yakni perlindungan terhadap agama, jiwa, akal, keturunan, dan harta benda. Peneliti juga menilai bahwasanya masyarakat masih memiliki pengetahuan yang kurang dengan sistem bagi hasil dan margin yang digunakan BMT BISMA. 


\section{Saran}

a. Kepada pihak BMT BISMA, terus mengembangkan kualitas terbaik produk-produknya dimasa yang akan datang, dan menampilkan promosi yang lebih menarik baik berupa brosur maupun spanduk, serta dapat memberikan kualitas pelayanan yang lebih baik lagi kepada nasabah/anggota dengan membuka cabang.

b. Diharapkan agar sebaiknya BMT BISMA tetap mempertahankan kemurnian dari maqashid syariah (nilai-nilai syariah) yang sudah diterapkan, dan dapat memberikan sosialisasi pengetahuan kepada anggota dan calon anggota tentang kajian Ekonomi Islam.

\section{DAFTAR PUSTAKA}

Al-Qur'an dan Terjemahnya

Abdullah, Taufik. 2002. Ensiklopedia Tematis Dunia Islam Jakarta: Pt Ichtiar Baru Van Hoeve.

Al-Din, Bin Zaghibah Izz. 1996. AlMaqashid al-Ammah li al-Syari'ah al-Islamiyah. Kairo: Dar al-Shafwah li al-Thaba'ah wa al-Nasyr wa alTauzi'.

Al-Ghazali, Abu Hamid Muhammad bin Muhammad. 1971. Shifa al-Ghalil, Tahqiq Hamdi Ubaid al-Kabisi. Baghdad: Mathba'ah al-Irshad.

Al-Jauziyyah, Ibn Qayyim. 1996. I'lam alMuwaqqi'in. Beirut: Dar al-Kutub al'Ilmiah.

Al-Raysuni, Ahmad. t.th. Nadzariyah alMaqashid Inda al-Imam al-Syathibi. Beirut: Al-Ma'had al-'Ali li al-Fikr al-Islami, al-Muassasah al-Jami'iyah li al-Dirasat wa al-Nashr wa alTawzi'.

Al-Syathibi, Abu Ishaq. t.th. al-Muwafaqat fi Ushul al-Syari'ah, Jilid. 3. Beirut: Dar al-Ma'rifah.
Amrin, Abdullah. 2007. Strategi Pemasaran Asuransi Syariah. Jakarta: PT Grasindo.

Arifin, Zainul. 2002. Dasar-Dasar Manajemen Perbankan Syariah. Jakarta: Alfabeta.

Assauri, Sofian. 2011. Manajemen Pemasaran. Jakarta: Rajawali Pers.

'Athiyyah, Jamal al-Din. 1988. AlNadzariyah al- 'Ammah li al-Syari'ah al-Islamiyah. t.tp.

Buku Profile Koperasi Syariah BMT BISMA.

David, Fred R. 2002. Manajemen Strategis: Konsep. Jakarta: PT. Prenhallindo.

Fathoni, Abdullah. 2015. Manajemen Risiko Kontemporer Bank, Koperasi dan BMT. Jakarta: Yayasan Pendidikan Nur Azza Lestari.

Fathoni, Abdurrahman. 2006. Manajemen Sumber Daya Manusia. Jakarta: Renika Cipta.

Fathurrahman, Djamil. 1997. Filsafat Hukum Islam. Jakarta: Logos Wacana Ilmu. .1995. Metode Ijtihad Majelis Tarjih Muhammadiyah. Jakarta: Logos.

Tjiptono, Fandy. 2015. Strategi Pemasaran. Yogyakarta: CV Andi Offset.

Khallaf, Abdul Wahab. 1996. Ilm Ushul Fiqh.Terj.Noer Iskandar al-Barsany dan Moh. Tolchah Mansoer. Jakarta: PT Raja Grafindo Persada.

Kotler, Philip dan Levin Lane Keller. 2009. Manajemen Pemasaran, Edisi Ketigabelas. Jakarta: Erlangga.

Miftah, A. 2015. Mengenal Marketing dan Marketers Syariah. Islamiconomic: Jurnal Ekonomi Islam.

Nasuka, M. 2017. Peningkatan Loyalitas Pelanggan Melalui Kepuasan Pelanggan dengan Layanan Inti (Suatu Pendekatan Konsep Islamic Marketing).Jurnal Syari'ah Dan Hukum Diktum. 
Nurhisam, L. 2017. Etika Marketing Syariah. Iqtishadia: Jurnal Ekonomi Dan Perbankan Syariah.

Praja, Juhaya S. 1995. Filsafat Hukum Islam. Bandung: LPPM Universitas Islam Bandung.

Rachmat. 2014. Manajemen Strategic. Bandung: CV Pustaka Setia.

Rianto Al-Arif, Muhammad Nur. 2012. Dasar-Dasar Pemasaran Bank Syariah, Bandung: CV Alfabeta.

Ridwan, Muhamad. 2006. Sistem dan Prosedur Pendirian BMT (Baitul Maal Wat Tanwil) Yogyakarta: Citra Media.

Rivai, Veithzal. Dkk.2017. Islamic Marketing Management. Jakarta: PT. Bumi Aksara.

Salam, Izzudin Ibn Abdis, Qawa id alAhkam Limashalih al-Anam, Kairo: Al Istiqamat.

Siagan P, Sondang. 2008. Manajemen Sumber Daya Manusia. Jakarta: Bumi Aksara.
Siamat, Dahlan. 1999. Manajemen Lembaga Keuangan. Jakarta: Fakultas Ekonomi UI

Shomad, Abdul. 2010. Hukum Islam: Penormaan Prinsip Syariah Dalam Hukum Indonesia, Jakarta: Kencana.

Sugiyono. 2011. Metode Penelitian (Pendekatan Kuantitatif, Kualitatif). Bandung: Alfabeta.

Susilo, Edi. 2018. Pengawasan Syariah pada Lembaga Keuangan Syariah. Yogyakarta: UPP STIM YKPN.

Steiner, George A, dan Miner John B. 1997. Kebijakan dan Strategi Manajemen.

Jakarta: Erlangga.

Syarifuddin, Amir. 1997. Ushul Fiqh Jilid II. Jakarta: Logos Wacana Ilmu

Zuhayli, Wahbah. 1986. Ushul Figh alIslami, Jilid 2. Damaskus: Dar alFikr.

Zuhri, Saifudin. 2009. Ushul Fikih: Akal sebagai Sumber Hukum Islam. Yogyakarta: Pustaka Pelajar. 
Analisis Kesesuian Strategi Pemasaran Terhadap Maqashid Syariah (Studi Kasus di BMT Bina Insan Sejahtera Mandiri) 